\title{
Kaum Profesional dan Pemerintahan yang Bersih: Pandangan Seorang Jurnalis
}

\author{
Ignatius Haryanto
}

\section{Pengantar}

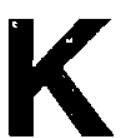

aum profesional sering disebut sebagai bagian dari kelas menengah yang diharapkan untuk menjadi agen perubahan. Pertanyaanya lalu berbunyi, apakah betul demikian? Lantas juga perlu dipertanyakan, perubahan terhadap apa? Mungkin terutama perubahan terhadap pemerintahan yang korup, sentralistis, pandai menggunakan kekerasan, serta mengabaikan aspirasi masyarakat luas. Pendeknya dalam iklim yang tidak demokratis, peran kaum profesional banyak diharapkan bisa membuka kebekuan yang ditimbulkan oleh sistem politik yang tidak terbuka. Contoh yang sering disebut untuk konteks Asia misalnya apa yang terjadi di Korea Selatan.

Apakah tema ini hanya sekedar harapan belaka, ataukah sudah terlihat ada gejala yang dapat disimpulkan sebagai mulai tumbuhnya kekuatan para profesional untuk menjadi kelompok penekan (pressure group) yang efektif kepada kekuasaan, agar kekuasaan mulai membuka dirinya dan menjadi lebih populer di mata masyarakatnya.

Tulisan ini tidak berpretensi ilmiah untuk membahas di mana peluang itu terbuka untuk kalangan profesional dan di mana tantangan menghadang kaum profesional untuk meretas jalan menuju pemerintahan yang bersih. Tulisan ini sekedar bercerita atas bidang yang penulis geluti, yaitu dunia jurnalistik, dimana di dalamnya juga terjadi tarik-menarik antara para jurnalis (yang mungkin masuk sebagai kaum profesional) dengan pemerintahan atau birokrasi yang diandaikan tidak:bersih.

\section{Sepintas tentang Jurnalis pada masa Awal Kemerdekaan}

Mengapa seorang Mochtar Lubis akhirnya memilih dirinya untuk menjadi seorang wartawan, adalah karena bujuk rayunya dari senior wartawan kawak yang kemudian menjadi salah satu wakil presiden, Adam Malik. Waktu itu Adam Malik yang memimpin kantor berita Antara, mengatakan sudah banyak orang yang berjuang untuk membela negeri ini dengan mengangkat bambu runcing tapi belum banyak orang yang berpikir bahwa pena pun menjadi senjata yang tak kalah ampuh dengan bambu runcing. Dari situ Mochtar Lubis pun akhirnya memutuskan untuk menjadi seorang wartawan (Atmakusumah, 1992, 60).

Mungkin ini kisah romantis yang digali dari sejumlah generasi awal. Tokoh seperti Mochtar Lubis, BM Diah, Rosihan Anwar 
ataupun angkatan sebelumnya seperti Adinegoro, Parada Harahap, Tirtoadhisoerjo, dan lain-lain, turut mewarnai sejarah jurnalis di negeri ini dengan segala pahit manisnya. Menjadi wartawan adalah turut menjadi pembela negeri, adalah idealisme yang dikobarkan oleh para jurnalis masa itu.

Boleh dikatakan juga bahwa sejumlah politikus Indonesia sejak awal abad 20, tak lain dan tak bukan adalah seorang jurnalis, atau setidaknya mereka memimpin suatu surat kabar ketika berjuang menuju Indonesia merdeka. Bahwa sejumlah mahasiswa sekolah kedokteran (Stovia) di awal 20 itu juga dikenal sebagai jurnalis. Sebutlah seperti Tjipto Mangunkuesoemo, Tirto Adhisoerjo dan lain-lain.

Posisi surat kabar itu memang memiliki peran penting yang tak dapat ditinggalkan begitu saja pada tahun-tahun pertama kemerdekaan. Sejumlah koran didirikan setelah kepergian Jepang untuk menyuarakan kemerdekaan bangsa dan biasanya pendirinya adalah seorang politikus.

Posisi wartawan mendapat tempat yang tinggi di mata pemerintahan saat itu. Pemerintahan republik yang masih muda usia, berharap agar para jurnalis ini bisa mémberitakan bagaimana kemerdekaan mau dicapai dan dipertahankan dengan program-program yang telah disiapkan sebelumnya. Tarik-menarik antara perang fisik di satu sisi dan perlawanan yang dilakukan lewat diplomasi di luar negeri dilakukan dengan mengundang partisipasi penuh dari para wartawan pada masa itu. Tiap kali terjadi perundingan ke luar negeri, hingga akhir tahun 1949, para jurnalis awal menjadi saksi sejarah terjadinya tarik menarik pihak sekutu dengan para pemuda Indonesia untuk membuktikan bahwa para pemuda ini sanggup untuk mendirikan suatu negara republik.

Sukarno Hattapun walau tidak lagi memimpin surat kabar sendiri (Sukarno dulu memimpin Pikiran Rakyat dan Hatta memimpin Indonesia Merdeka di Belanda), masih melihat surat kabar sebagai salah satu komponen penting untuk mengisi informasi kepada masyarakat baru tersebut. Tak berlebihan jika suatu saat Mochtar Lubis pernah bercerita bahwa para jurnalis saat itu sangat dekat dengan presiden. Walau sudah menulis hal-hal yang kritis tentang Sukarno atau kebijakan Sukarno atau kebijakan Sukarno, presiden pertama RI ini tak pernah lupa untuk mengundang wartawan menghabiskan akhir minggu di istana Bogor. Mochtar bahkan bercerita kalau mereka amat mudah bertemu dengan presiden atau para menteri. Tidak perlu berhadapan dengan para ajudan atau sekretaris yang akan menghalangi bila bertemu dengan para menteri tersebut.

Pengalaman tarik-menarik antara pers dengan birokrasi negara baru terjadi pada tahun 50-an, saat berlangsungnya masa demokrasi konstitusional. Sebenarnya yang saat itu terjadi adalah imbas politik ideologis yang juga terjadi dalam tubuh pers. Sebagaimana kita ketahui bersama bahwa pada masa tersebut, banyak pers mengambil suatu partai politik sebagai afiliasinya, dan kabinet yang berjalan pada tahun 50an tersebut adalah kabinet yang banyak berganti tergantung dari dinamika politik yang terjadi. Satu kali kabinet dikuasai oleh Partai Nasional Indonesia, kali lain dikuasai oleh Masyumi atau kabinet koalisi. Demikian jugalah pers yang mengkritik pemerintahan saat itu pun berganti-ganti. Saat Masyumi memimpin, koran dari Partai Nasional Indonesia akan banyak mengkritik kebijakan kabinet tersebut. Begitupun sebaliknya, jika PNI yang berkuasa.

Namun pada masa Demokrasi Terpimpin para jurnalis pun beroleh pengalaman yang tidak cukup mengenakkan dengan adanya sejumlah pembredeilan atau penutupan surat kabar yang mereka 
alami sejak tahun 1957, saat Indonesia diumumkan dalam keadan darurat perang (Lihat pada Smith 1989). Puluhan surat kabar terkena tindakan represi dari pemerintahan ketika Demokrasi Konstitusional berhenti berjalan dan dianggap tidak pantas untuk diteruskan, dan diambil alih oleh Sukarno dan ABRI. Indonesiapun masuk dalam era Demokrasi Terpimpin. Kekuasaan terpusat pada presiden diberlakukan, kembali pada UUD 45 itulah artinya, presiden adalah penguasa tertinggi perang, Panglima Besar Revolusi dan berbagai sebutan lainnya.

\section{Konstruksi Hubungan Pers dan Pe- merintah pada Masa Orde Baru}

Pada masa peralihan kekuasaan pada tahun 1965-66 juga ditandai dengan kelahiran sejumlah pers generasi baru, baik koran yang dibentuk sebelum terjadi peralihan kekuasaan seperti Kompas, Sinar Harapan maupun Angkatan Bersenjata atau Berita Yudha. Dan sejumlah koran yang dulunya sempat ditutup pada masa Demokrasi Terpimpin, akhirnya kembali terbit. Bisa disebut di sini adalah koran seperti Indonesia Raya, Pedoman dll. Sejumlah koran mahasiswa pun tampil ke permukaan, seperti mingguan Mahasiswa Indonesia di Bandung, Harian KAMI di Jakarta dan beberapa pemilik kampus masing-masing.

Beberapa orang masih percaya bahwa yang disebut antara tahun 1966-74 adalah masa bulan madu antara pers dan pemerintahan Orde Baru. Saya menilainya agak lain. Buat saya konstruksinya saat itu adalah pers dan kekuasaan yang baru memiliki kepentingan yang sama pada masa peralihan kekuasaan tersebut. Sejumlah eksponen pers juga turut dalam aktivitas politik menentang pengaruh komunis yang lebih besar ataupun kebencian yang ditujukan kepada Sukarno. Ketika penguasa baru muncul, yaitu Jend Soeharto yang memulai karirnya sebagai panglima Kostrad lalu pemegang Supersemar, sekaligus kepala Kopkamtib, dan akhirnya sebagai Presiden dalam Sidang Umum tahun 1969, maka muncul harapan bahwa masa yang baru akan lebih baik daripada masa sebelumnya.

Banyak orang yang belum apa-apa sudah memberikan dukungan moral yang demikian hebat kepeda pemerintahan yang muda usia, dan masih belum diuji dalam saat mengatasi krisis ekonomi dn politik saat itu. Orang seperti Mochtar Lubis yang dibebaskan dari penjara tahun 1968 (setelah 10 tahun mendekam di dalamnya) misalnya dalam edisi pertama koran Indonesia Raya periode kedua masa hidupnya menulis tajuk rencana yang demikian menyokong pemerintahan yang baru;

Harian ini memberikan dukungannya pada pemerintah Suharto dan akan memberikan sumbangan sebesar mungkin menciptakan iklim yang sehat dan konstruktif di negeri kita, agar program-program pembangunan ekonominya untuk kemakmuran rakyat yang merata dan adil mendapat sukses sebesar mungkin.

Akan tetapi kami juga akan memberikan kritik-kritik dimana dan apabila kami anggap perlu dengan tujuan senantiasa supaya pemerintah kita yang sekarang, pimpinan nasional kita yang baru, berhasil dalam tugas berat mereka memperbaiki kehancuran dan kerusakan di segala bidang penghidupan bangsa kita yang telah ditimbulkan oleh bekas regim Sukarno.

Kami akan bekerja menyadarkan pendapat umum rakyat kita pada kenyataan bahwa pekerjaan yang berat itu akan meminta waktu yang cukup lama, akan meminta disiplin nasional yang tinggi, rasa tanggung jawab sosial dan nasional yang sebesar-besarnya, kerja keras dan pengabdian yang seluhur-Juhurnya dari setiap kita, pemimpin atau rakyat umum. Kehadiran Indonesia Raya adalah juga per- 
nyataan kepercayaan dan keyakinan kami pada pimpinan nasional bangsa kita yang baru, serta kepercayaan dan keyakinan kami pada mungkinnya seluruh keadaan di negeri (ini) diperbaiki dan dimajukan.

Kami mengulurkan tangan persahabatan dan persaudaraan pada setiap golongan di negeri kita yang sama-sama bercita-cita untuk membina masyarakat yang adil dan makmur merata dan yang menjamin hak-hak asasi manusia. Tiada seorang pembesar, seorang Jendral, seorang pemimpin politik, seorang menteri harus merasa khawatir atau takut dengan munculnya kami ke tengah gelanggang. Kami akan menyokong dan memberi pujian pada mereka selama mereka melakukan tugas dan kewajiban mereka untuk kepentingan rakyat dan bangsa. Kami akan menjadi pembela mereka untuk kepentingan rakyat dan bangsa. Kami akan menjadi pembela mereka yang paling gigih selama mereka berjalan dalam kebenaran dan keadilan (Tajuk Rencana Indonesia Raya tanggal 30 Oktober 1968).

Kalau hendak dikatakan, dari teks di atas terihat betapa muncul rasa terimakasih yang diucapkan oleh Mochtar Lubis karena ia telah dikeluarkan dari penjara oleh pemerintahan yang baru, tapi kemudian pertanyaanya adalah; seberapa lama kepentingan antara jurnalis dan kekuasaan yang baru akan terus beriringan? Apakah mereka akan terus memiliki kepentingan yang sama? Dan ini sebenamya pertanyaan pokoknya-apa sesungguhnya alasan keberadaan (rasion d'etre) dari suatu penerbitan pers, dan pemerintahan dari suatu negara. Apakah dan bagaimanakah fungsi masingmasing yang dijalankan untuk itu?

Dalam perjalanan sejarah pertanyaan tadi dijawab bahwa kepentingan antar keduanya tidak selalu seiring, bahkan ada suatu titik di mana keduanya sadar bahwa kepentingan mereka berbeda sambil mengingat bahwa memang dulu ketika bertemu di titik yang sama, itu adalah representasi dari kepentingan sesaat yang memang sejalan. Tapi titik temu tidak selalu bisa diteruskan, karena masing-masing institusi memiliki corak dan karakter yang membedakan satu dengan yang lainnya. Demikianlah pemerintahan baru yang merupakan aliansi dari kekuatan teknokrat, militer dan sokongan mahasiswa, menemui titik dimana pers harus melepaskan diri dari bayangbayang kekuasaan. Fungsi informasi yang dilakukan oleh Pers, menuntut adanya keterbukaan, transparansi, cukup jelas untuk dicerna untuk masyarakat kebanyakan, dan ini semua artinya pers menekankan fungsi sosial kontrol yang dilakukanya. Tapi lalu persoalanya, apakah kekuasaan yang baru sungguth mau dikontrol atau tidak?

Logikanya begini, bahwa kekuatan baru dalam kekuasaan saat itu masih sibuk mengkonsolidasikan dirinya untuk membentuk suatu pemerintahan yang kuat, dengan program pembangunan yang mereka utamakan, dan untuk itu seperti trilogi pembangunan yang dijadikan prasyarat (stabilitas nasional, pertumbuhan ekonomi dan pemerataan ekonomi) untuk pemerintahan baru berjalan. Unsur dari kelompok lama, golongan komunis, golongan PNI dan segala organisasi yang berada di bawah naunganya, diberesi terlebih dahulu. Mulai dari MPRS, kabinet, gurbenur-gurbenur, panglima-panglima daerah, hingga ke tingkat yang paling mikro, lurah, camat, kepala desa, bahkan sampai tingkat massa. Maka inilah penjelasan yang diberikan kepada pertanyaan mengapa terjadi pembantaian yang demikian meluas pada awal Orde Baru tersebut (Lihat pada disertasi yang baru saja diselesaikan oleh Hermawan Sulistyo; The Forgetten Years; The Missing History of Mass Slanghter 1965-66; In Kediri, Jombang, tesis Doktor dari Arizona State University, 1997). 
Bangunan yang barupun disiapkan. Ada konsensus nasional, ada depolitisasi masyarakat, ada penyerdehanaan partai-partai, ada pembentukan kino-kino di bawah Golkar, ada konsep Monoloyalitas, ada paket UU Politik yang disodorkan, siapapun yang menyodorkan konsep demikian. Yang jelas adalah kekuasaaan yang baru mencoba menata ulang konstruksi kehidupan masyarakat yang mereka sebut sebagai era pembangunan.

Namun dalam saat benah-benah pemerintahan yang baru ini, apakah kekuasaan juga membuka diri atas kontrol, atas kritik dari masyarakat atau lewat pers? Rupanya inilah yang tidak dianggap sebagai input yang mendukung pembangunan. Memperbesar pendukung kekuasaan yang baru, itulah yang lebih didahulukan sebagai jaminan untuk melangsungkan program-program politik pembangunan yang sudah dirancang.

Dengan penjelasan ini maka kepentingan antara pers di satu sisi dengan kepentingan kekuasaan di sisi lain, mulai tampak berpotensi untuk berpisah.Dan demikianlah halnya yang tejiadi. Pada tahun 1974, suatu pembredeilan massal dilakukan terhadap 14 koran dan majalah selepas terjadinya peristiwa 15 Januari 1974. Peristiwa itu sendiri merupakan kerusuhan yang terjadi di Jakarta dan di beberapa kota lain berupa pengrusakan sejumlah toko, pembakaran dan perampokan. Kelompok mahasiswa dituding sebagai pelaksana kerusuhan tersebut, walaupun tuduhan demikian disangkal oleh mahasiswa dan balik menuduh bahwa ada kelompok lain yang ingin menjelekan citra protes mahasiswa.

Pemberitaan pers tentang peristiwa kerusuhan dan pemberitaan tentang protes mahasiswa sebelumnya, dianggap oleh penguasa sebagai tindakan yang memanasmanasi situasi (tuduhan klise yang selalu diulang untuk tiap momen serupa) dan me- ngadu domba diantara kepentingan nasional.

Betul atau tidak tuduhan itu, bukan soal yang mau dibahas, tapi momen ini menjelaskan bahwa titik perpisahan sudah ditemukan. Fungsi pers, fungsi informasi, fungsi kontrol sosial bukanlah kepentingan yang sejalan dengan kekuasaan yang sedang menancapkan pengaruh ataupun memperluas wilayah kekuasaanya, apalagi kalau kekuasaan itu dimotori oleh kalangan militer. Jadi jelaslah adagium yang populer; Dalam politik, tidak ada musuh atau kawan sejati, yang ada adalah kepentingan sejati.

Sejauh kepentingan bisa berjalan, kita akan bergandengan tangan, namun jika kepentingan sudah mulai berbeda, mungkin kita akan menggandeng pihak yang lain lagi.

Para jurnalis yang mencoba membuka ruang kebebasan pers yang lebih, beroleh ganjaran dengan penutupan sejumlah koran pada tahun 1974, penutupan sementara 7 buah koran pada tahun 1978 dan beberapa kasus penutupan media cetak lainnya pada dekade 80-90-an.

\section{Pers Industri dan Fenomena Wartawan Amplop}

Pergeseran nilai yang dianut dalam pers indonesia terjadi dalam cara yang cukup drastis. Pers yang tadinya agen kultural, yang lebih dekat dengan nuansa perjuangan atau keterlibatan dalam masalah .demokrasi pelan-pelan berubah menjadi agen kapital, saat industri pers merebak dan sejumlah pemodal besar masuk dalam industri yang memang cukup menguntungkan ini. Inilah fenomena pers pada dekade 80-90-an.

Adalah salah satu sisi gelap yang jarang sekali mau dibuka oleh para jurnalis sebagai bagian lain dari kemunculan pers industri ini, adalah menyangkut masalah amplop. Wartawan amplop ataupun jurna- 
lisme amplop yang dimaksud adalah jurnalisme yang dibangun atas dasar amplopamplop (berisikan uang) yang diberikan oleh sejumlah nara sumber untuk menjaga kepentingan mereka. Yang mereka inginkan adalah, agar wartawan tidak menulis yang negatif tentang si pengusaha ataupun instansi yang mereka pimpin.

Adalah ritus biasa setelah terjadi konfrensi pers, para wartawan dikumpulkan untuk diberi amplop. Sebaliknya para wartawan pun banyak yang memang mengejar amplop. Jadi hubungannya memang resiprokal. Tak dapat dikatakan mana yang lebih dulu menawarkan amplop tersebut.

Persoalan wartawan amplop ini bukan soal moral, apakah baik atau tidak menerima amplop. Persoalanya tidak semudah itu Saya melihatnya sebagai persoalan yang lebih struktural sifatnya. Tak sedikit cerita bahwa seorang wartawan diberi penghasilan yang sangat minim, di bawah standard UMR atau cuma dibekali kartu PWI. Bagaimana cara ia mencukupi penghasilannya, itu diserahkan pada 'kebijakan' dan 'kreativitas' si wartawan untuk menutupi yang tak cukup itu. Jadilah wartawan seperti ini mereka yang mengejar acaraacara konfrensi pers, karena biasanya konfrensi pers selalu diikuti dengan pembagian amplop.

Namun salah seorang rekan wartawan mengkritik cara pandang saya yang semata-mata melihat soal wartawan amplop dikaitkan dengan kurangnya jaminan kesejahteraan dari perusahaan dimana ia bekerja. Rekan ini mengatakan ada jenis wartawan amplop yang lain yang justru membutuhkan amplop tersebut karena sifat keserakahanya. la ingin mendapatkan yang lebih banyak materi yang didapatnya secara resmi. Jenis yang belakangan ini tentu saja bekerja dengan cara yang amat canggih dan tidak dengan terang-terang meminta secara fisik amplopnya, tapi mungkin me- nyodorkan nomor rekening di Bank yang ia miliki, untuk tiap bulannya disetori oleh perusahaan atau instansi tertentu untuk menjamin amanya berita yang dikeluarkan media tersebut. Bagaimanapun ia tahu ada kebobrokan di dalam suatu instansi, ia tetap diam saja karena ia mengkreasi pemberitaan yang memuat hal positif saja. Atau bisa juga karena skenarionya lebih canggih, si wartawan justru dipakai untuk memukul saingan suatu perusahaan, dengan membuat berita-berita negatif yang pada akhirnya akan membuat harga saham sahamnya makin merosot.

Fenomena terakhir ini adalah fenomena yang makin kompleks yang akan dihadapi oleh pers Indonesia. Kesadaran sebagaj agen kultural pelan-pelan sudah ditinggalkan, dan kesadaran yang tinggal adalah kesadaran sebagai agen kapital. Belum banyak orang sadar soal ini maupun memahami soal lebih rumit daripada yang dibayangkan selama ini. Permainan citra berita ataupun bias-bias yang sengaja ditonjolkan mau tak mau menyertakan pers sebagai salah satu pelakunnya (ilustrasi yang 'brutal' untuk soal ini bisa dilihat dari novel terjemahan Gramedia Pustaka Utama, 1997, Almghty dan The Fourth Estate yang ditulis Irving Wallace dan Jeffrey Acher. Disertasi soal Pers yang paling akhir pun, Daniel Dhakidae, belum menyentuh fenomena ini, ia hanya menjelaskan pergeseran dari pers politik ke pers industri. Tapi bagaimana sesungguhnya operasi yang terjadi dalam dunia pers kontemporer sebagai konsekuensi logis menjadi agen kapital tadi, belum banyak ditunjukkan. Beberapa penulis luar yang menulis soal ini misalnya Graham Murdock ataupun Ben Bagdikian).

Sadar atau tidak, langsung atau tidak, kemunculan wartawan amplop ini adalah salah satu cacat dalam profesi jurnalistik. Di mana banyak wartawan masuk dalam golongan ini dan cuman penerbitan yang 
cukup besar dan mampu menggaji karyawanya secara layak, akan memberlakukan peraturan yang ketat untuk soal amplop ini. Bila salah seorang wartawan mereka diketahui menerima amplop, biasanya tak ada ampun, si wartawan akan dikeluarkan dari penerbitan tersebut.

Sebenarnya peran dari organisasi profesi dan kebijakan negara dalam menghasilkan situasi yang kondusif untuk memunculkan golongan wartawan amplop patut disebutkan juga. Organisasi profesi seperti PWI cenderung menutup mata atas persoalan ini, dan menganggap itu lebih merupakan persoalan intern dari masing-masing penerbitan. Bahwa ada citra yang terlunturi dengan persoalan amplop ini tak terlampau dipedulikanoleh mereka. Bahkan yang paling mengejutkan adalah ketua PWI sendiri pernah berkata bahwa amplop bukanlah suatu yang haram. Sedangkan pemerintah sendiri juga punya kontribusi atas kemunculan masalah amplop ini.selain sebagai salah satu pelaku yang memunculkan ketergantungan macam ini, secara makro, dalam urusan policy menerbitkan SIUPP bagi penerbitan-penerbitan baru tidak pernah memikirkan soal ini.

Soal wartawan amplop dikemukakan uniuk mengatakan bahwa kaum profesional inipun memiliki cacat dalam praksisnya mereka bukan yang paling bersih dan bisa berteriak bahwa mereka yang paling berhak untuk mengumandangkan soal clean goverment.

\section{Citra Profesi yang makin menurun di mata birokrasi Negara}

Kalau wartawan pada jaman Mochtar Lubis atau Rosihan Anwar, sangat mudah bertemu dengan presiden Sukarno atau para menteri lainnya, karena ada perasaan kesetaraan diantara keduanya. Wartawan pun salah seorang pejuang bangsa, dan para anggota eksekutif pun masih memiliki semangat pengabdian kepada bangsa dan negara yang tinggi. Maka mereka pun sangat dekat dan menganggap wartawan adalah posisi yang sejajar dengan mereka Tapi cerita seperti itu mungkin sulit berulang, karena 30 tahun pengalaman masa Orde Baru, menunjukkan peran wartawan semakin terpuruk adanya.

Wartawan boro-boro bisa bertemu muka dan berwawancara dengan presiden (mungkin hanya pernah dilakukan pada masa awal Orde Baru, dan salah satu misalnya diwawancarai oleh wartawan Kompas yang berpangkalan di New York, almarhumah Thres Nio) untuk bertemu muka dengan para menteri pun dianggap sulit. Apalagi dengan adanya kompleksitas dalam birokrasi saat sekarang, biasanya wartawan hanya akan berjumpa dengan petugas atau kepala Humas, atau tingkat Dirjen misalnya.

Mengapa hal ini bisa terjadi, mungkin karena dalam 30 tahun, tak banyak yang berubah dalam komposisi birokrasi Orde Baru, sedangkan perkembangan yang cukup pesat terjadi dalam profesi jurnalis. Tiap tahun selalu ada wartawan baru, ada juga penerbitan baru yang langsung tak langsung memunculkan generasi-generasi baru dalam profesi jurnalistik, tidak lagi seperti Rosihan Anwar dkk, tapi sudah beralih pada generasi pers industri seperti Kompas, Republika, Tempo, Jawa Pos dan lain-lain.

Secara demografi saja usia dari Birokrasi makin tua, dan pemimpin birokrasi itu sendiri sudah 30 tahun lebih berkuasa dan praktis tidak banyak lagi mengenal generasi berikut di bawah usianya. Sedangkan dinamika banyak terjadi dalam profesi jurnalistik. Bahkan dinamika yang cepat ini adalah elemen penting dalam dunia jurnalistik yang sejajar dengan perkembangan tekhnologi komunikasi yang sangat cepat. 
Koran model konvensional tak lagi laku, karena yang dibutuhkan saat ini adalah penerbitan yang bercorak industri, dengan semangat penguasaan soal tekhnologi dan tingkat persaingan yang tinggi. Penerbitan macam begini lebih memperhatikan soal pasar atau pembaca, dan juga cenderung membuka dialog kepada masyarakat. Televisi yang menjamur sejak beberapa tahun terakhir ini dan menimbulkan persaingan yang lebih tajam antara dua macam media massa ini. Belum lagi saluran bebas sensor (tapi tidak bebas dalam pelacakan alamatnya) yaitu internet.

Dalam dimensi yang lain, tiap penerbit baru muncul, maka usia pemimpin redaksinya menunjukkan kecenderungan yang semakin muda ketimbang generasi sebelumnya. Terjadi regenerasi yang sebenarnya hal alamiah yang terjadi dalam suatu institusi yang dinamis.

Hubungan profesi jurnalistik dengan kehidupan masyarakat lebih dekat karenanya.Bagaimana suatu media dicintai masyarakat atau tidak, langsung terasa dalam bentuk oplag ataupun respon atas pemberitaan oleh media yang bersangkutan. Sekali terjadi, suatu media gagal mempertahankan kredibilitasnya di depan masyarakat, maka penerbitan itu ibaratnya sudah tidak memiliki jiwa atau rohnya. la tinggal survive untuk terus bisa bertahan hidup. Masyarakat adalah hakim yang adil untuk profesi jurnalis. Dan dalam iklim dimana kebebasan pers tidak cukup dibuka, maka penerbitan yang kritis, atau penerbitan yang menawarkan gagasan yang lebih masuk akal di mata masyarakat dan memberikan kepuasan atau keingintahuan pembaca, maka penerbitan tersebut akan lebih dipilih oleh masyarakat:

Namun tak demikian halnya posisi pers di mata birokrasi. Birokrasi negara seperti Orde Baru sekarang, dengan segala julukannya, mulai dari Beamstaadt, birokrasi rente, military authotarian state, model pemerintahan kolonial Belanda, ataupun model pemerintahan kolonial Jepang dil, punya sejarah setidaknya dalam 30 tahun terakhir ini tak pernah memberi ruang yang cukup bebas bagi pers.

Pers yang mencoba kritis kepada pemerintah, menampilkan pemberitaan yang memihak masyarakat, menyoroti keboborokan birokrasi, mempromosikan pemerintahan yang bersih, akan beroleh ganjaran dengan penghukuman-penghukuman yang dideretkan bagai suatu litani dari masa ke masa.

Koran Indonesia Raya pada tahun 70an misalnya, banyak mengangkat ketidakberesan pengelolaan uang dalam Pertamina (lihat Haryanto, dan kumpulan Tajuk Rencana Indonesia Raya) lalu juga efek negatif dari masuknya modal Jepang ke Indonesia, memperoleh ganjaran dengan penutupan koran tersebut pada tahun 1974.

Empat tahun kemudian pola ini kembali terjadi. Para mahasiswa UI dan ITB juga menyuarakan ketidak-puasan mereka terhadap pengelolaan pemerintahan yang cenderung menghasilkan kesenjangan sosial yang besar, pemerintahan yang korup, dan tidak transparan. Militer saat itu memiliki peran yang demikian besar, apalagi masih adanya kelembagaan ekstra konstitusional yang bisa menangkap, memeriksa bahkan menahan orang tanpa lewat'prosedur resmi, seperti Kopkamtib.

Aksi protes mahasiswa ini dilaporkan sejumlah media di Jakarta, dan momen setelah terjadinya Pemilu kedua pada masa Orde Baru ditanggapi dengan sikap mahasiswa yang sangat tégas, bahkan meminta agar Jendral Soeharto tak lagi dijadikan pemimpin nasional. Namun mahasiswa pun dipukul karena sikapnya, demikian pula para media yang banyak memberitakan aksi protes tersebut. Kekayaan pejabat juga mulai dipersoalkan pada masa itu. Tujuh 
penerbitan harus berhenti sementara, sebelum akhirnya diijinkan kembali setelah menandatangani sejumlah kesepakatan untuk menghindari pemberitaan-pemberitaan yang dianggap tabu.

Jadilah suatu pola baku dalam penanganan masalah keamanan di negeri ini; berangus dulu pers, kendalikan massa, bungkam mahasiswa di kampus, kalau perlu ajukan ke pengadilan, acuhkan wakil rakyat di DPR. Itu semua mengatasnamakan keamanan negri dan berlanjutnya pembangunan nasional. Cita-cita untuk pemerintahan yang bersih yang juga diidamkan oleh Pers akan beroleh tamparan-tamparan seperti itu.

Perlakuan pemerintah kepada pers yang membatasi kebebasanya, terus berlanjut memasuki tahun 80-an. Koran-koran kritis seperti Sinar Harapan; Prioritas yang giliran mendapat ganjaran ini ketika memberitakan suatu rancangan APBN sebelum waktunya dan juga masalah hutang luar negeri Indonesia. Pada tahun 90-an, pembredelan atas 3 buäh mingguan, Tempo, Detik dan Editor, juga karena kekritisan pémberitaan mereka kepada birokrasi. Tempo ditutup gara-gara. memberitakan pemberedeilan kapal perang bekas Jerman Timur yang menimbulkan polemik antara Menteri Keuangan Marie Muhamad dan Menteri Negara Riset dan Tekhnologi, BJ Habibie. Dan Detik yang sebenarnya berusia 2 tahun, ditutup karena akumulasi pemberitaan yang dianggap tidak menguntungkan posisi pemerintah. Edisi sebelum mereka ditutup misalnya menulis soal calon - presiden baru.

Perlakuan yang kasat mata. Lebih mudah dilihat dan dirasakan, namun bagaimana dengan perlakuan birokrasi yang tidak mudah dilihat dan dirasakan oleh masyárakat banyak. Rupanya ada mekanisme tersendiri untuk menghalangi berbagai peran yang dibawakan oleh media massa untuk mengontrol pemerintahan yang bersih. Regulasi yang kelihatanya sepele justru bias menjadi bumerang yang mematikan. Soal-soal tekhnis administratif kini dominan dilakukan untuk menggeser perlakuan yang sangat drastis berupa penutupan atau pembredelan. Rupanya reaksi masyarakat luas di Indonesia atas pembredeilan Tempo dan juga dibawanya kasus ini ke peradilan (dan menang dua kali di tingkat PTUN dan PTTUN namun dikalahkan di tingkat MA) membuat pemerintah jadi waspada untuk mengulangi pola represi yang demikian.

Represi pun dialihkan untuk menyoal soai-soal seperti rekomendasi pemred dari PWI, persoalan keanggotaan PWI diantara penerbitan yang ada, bahkan persoalan missi penerbitan yang ada dalam SIUPP. Dan.untuk itu korbannya sudah banyak dan segera inipun ditangkap sebagai mekanisme kontrol dalam bentuk baru:

Rupanya pemerintahan yang tidak mau dikontrol menyiratkan adanya ketidakbersihan dalam pengelolaan pemerintahan. Tidak mau dikontrol jika memang pemerintahannya bersih, bukanlah suatu logika yang bisa diterima, karena pemerintahan yang bersih, dalam arti menggunakan kekuasaan pada batas kewenanganya, adalah prinsip yang menyiratkan adanya demokrasi, adanya keterbukaan dan adanya transparansi. Dan pemerintahan seperti ini, berarti terbuka terbuka untuk dikritik, untuk dievaluasi dan diberi masukan. Dan dalam kalangan birokrasi sendiri banyak dikenal para pekerja yang ulet, bersih dan jujur. Namun jenis seperti ini ibarat mencari-binatang langka di belantara hutan kita. Atau, si pejabat jujur ini tidak banyak bicara kepada pers, cederung menutup diri atau pejabat ini paling hanya bertahan dalam waktu yang tidak lama.

Harus disebut disini jenis pejabat lurus seperti Marie Muhamad, mantan menteri keuangan yang dikenal pandai memilih wak- 
tu kapan harus bicara pada pers, dan kapan hal itu tidak dilakukanya. Marie adalah seorang yang sangat disiplin menjaga rapat mulutnya jika ada problem besar yang dihadapinya sebagai menteri keuangan. Namun ketika ia harus membuka suara kepada pers, ia akan mengemukakan hal secara terbuka, walau tak seluruhnya disampaikan. Walau lebih dikenal pelit, tapi orang seperti Marie Muhamad justru oleh para wartawan dianggap sebagai pahlawan atau tokoh baik dalam kisah-kisah roman. Bisa diingat reaksi yang disampaikan oleh para pekerja media saat perpisahan dilakukan dengan Marie Muhamad. Marie tersenyum lebar mengakhiri masa tugasnya, dan sudah lama mungkin ia sadar bahwa pejabat seperti dirinya-yang lurus, tegas namun banyak menyimpan beban berat dari pimpinan dan lingkungan lain di sekitarnya-tidak akan bertahan lama.

Dapatlah dikatakan di sini bahwa segala diskusi publik ataupun opini yang saling bersliweran di masyarakat tentang pemerintahan yang bersih, boleh tampil dalam halaman-halaman muka surat kabar. Tapi jika ada media yang mulai berani untuk menampilkan suatu kasus nyata yang masuk kategori menyimpang dari pemerintahan yang bersih, tutup pintu rapat-rapat, kunci mulut erat-erat, dan yang diterima oleh pers tidak lain, tidak bukan (dan kaum pers pun selalu maklum dengan respon ini) peryataan "no comment" ataupun segala bentuk penyangkalan atas pemberitaan tersebut. Betapapun jelas fakta yang muncul di depan mata. Kasus kekayaan menteri perhubungan Haryanto Dhanutirto, kasus Jamsostek Abdul Latief, Menteri Pertambangan IB Sudjana dll.

Tiap tahun pula, pers biasanya mendapat laporan-laporan dari kelembagaan independen dari luar negeri yang memberi peringkat atas perfoma Indonesia di dunia keuangan. Kelembagaan seperti Standard
\& Poor's Corp, Transparancy International ataupun PERC yang selalu menggambarkan Indonesia sebagai negara korup, ekonomi berbiaya tinggi dan memiliki ketidakpastian dalam pengelolaan keuangan. Sebagai jurnalis yang mencoba mencover side, maka jurnalis akan bertanya komentar dari para pejabat pemerintah atas pemeringkatan semacam itu. Dan jawaban standar sudah ada di kepala jurnalis sebelum ia menanyakan soal itu; "Tendensius, misleading, tidak benar alat ukurnya, salah metodologinya atupun nilai-nilai kita tidak bisa disamakan dengan nilai-nilai Barat, kita memiliki nilai tersendiri'.

\section{Organisasi Profesi dan Kukungan Birokrasi Negara}

Pelbagai organisasi kita temui saat ini, namun beberapa di antara mereka yang betul-betul independen dan bisa menyuarakan kepentingan anggotanya, yaitu kaum profesional, yang juga punya kepentingan untuk terbentuknya pemerintahan yang bersih. Demikian juga yang terjadi dengan organisasi profesi seperti PWI. Kompartemensi atau kooptasi negara atas kelompok profesi sudah dimulai sejak awal Orde Baru, ketika sejumlah organisasi kemasyarakatan di taruh di bawah kelembagaan tunggal dan dipayungi pemerintahan Orde Baru. Para Guru harus menjadi anggota PGRI, pegawai negeri harus menjadi anggota KORPRI, para petani harus menjadi anggota HKTI para nelayan harus menjadi anggota HNSI, istri pegawai negeri harus menjadi anggota Dharma Wanita, para pemuda harus bernaung di bawah KNPI, atau para buruh haruslah menjadi anggota SPSI.

Model-model penyeragaman seperti itu perlahan-lahan meredusir kemampuan organisasi masyarakat menjadi model atau wadah tunggal sebagaimana yang telah disodorkan kepada masayarakat. Namun pe- 
Topik: Kaum Profesional dan Pemerintahan yang Bersih, Ignatius Haryanto

nyeragaman macam begini tak selalu berjalan dengan mulus, selalu ada tantangan dari masyarakat, yang menunjukkan adanya peningkatan kesadaran masyarakat dan juga model penyeragaman sudah terbukti kuno, usang, tidak efektif dan tidak bermakna apa-apa selain daripada mobilisasi massa dan monopoli organisasi profesi di bawah kekuatan pendukung Orde Baru. Kalau dalam bahasa yang lebih lugas, untuk menyebut tentang organisasi wartawan, Soedjati Djowandono, mengatakan bahwa PWI ibarat jalan menuju kekuasaan (road to power) dari para anggotanya untuk naik kelas kekuasaan yang lebih tinggi.

Artinya organisasi profesi tak lebih dari sekedar batu loncatan (stepping stone) untuk meraih kekuasaan yang lebih besar, dan bukan berfungsi sebagai wadah kaum profesional untuk makin meningkatkan mutu profesi, menjawab aspirasi ainggotanya dan mendesakkan kepentingan yang melindungi kepentingan anggota. PWI tak pernah bereaksi keras atas pembredeilan sejumlah penerbitan.

Apakah kehadiran seorang bekas anggota profesi menjadi pejabat pemerintah merupakan suatu hal yang membanggakan dan mengangkat martabat dari organisasi profesi tersebut? Belum tentu, kita harus lihat dulu, siapa orangnya dan kepentingan apa yang lebih ia dukung sesungguhnya. Jangan-jangan justru karena ia berasal dari suatu kelompok organisasi profesi ia justru sedang dikooptasi tanpa sadar untuk mengkhianati raison d'etre organisasi profesi tersebut. Apa yang bisa dikatakan tentang seorang mantan wartawan kemudian menjadi pejabat dan menutup sejumlah penerbitan, bahkan tempat dulu ia pernah bekerja?

Ini memang strategi besar dari politik Orde Baru yang mendepolitisasi masyarakat dan meniupkan ideologi pembangunan dengan penekanan pada logos stabilitas nasional. Apapun menjadi korban yang harus direlakan atas nama pembangunan. Bahkan dalam jurnalistik pun dikenal istilah pers Pancasila yang sebenarnya tak pernah jelas apa rumusanya. Jangan-jatigan ini cuma silat lidah dari penguasa untuk memberi nama agar tidak sama dengan sisi negatif dari sitem pers liberal dan sisi negatif dari pers komunis. Bahkan sebagai konsep pun istilah pers Pancasila tak cukup bisa bersaing dengan ideologi-ideologi lainnya.

Jangan-jangan sebenarnya sistem pers yang mau diciptakan secara baru oleh pemerintah Orde Baru ini tak lain dan tak bukan dari sistem pers biasa saja, tanpa muatan ideologi besar apapun, namun dikelola dengan sentralisasi kekuasaan di tangan negara dan pemodal. Dan pemodal inipun adalah pemodal yang direstui kehadirannya oleh negara.

Karena untuk menjawab operasionalisasi dari istilah Pers Pancasila, apakah Pers yang bisa membredel penerbitan yang tak disukai pemerintah, ataukah Pers Pancasila jugakah yang memungkinkan sejumlah wartawan kritis tak lagi boleh bekerja sebagai wartawan dan cenderung dimatikan hak-hak sipilnya? Apakah pers Pancasila jugakah namanya jika dilakukan pendiktean atas urusan redaksi oleh aparat keamanan dan birokrasi negara serta pemodal. Apakah Pers Pancasila jugakah namanya jika terus-menerus himbauan, ancaman, budaya telepon, pemanggilan, intimidasi bahkan pembunuhan terhadap para wartawan saat menjalankan tugas mereka? Dan mari kita dengar apa saja yang pernah dilakukan organisasi profesi seperti PWI atas sejumlah soal di atas. Bagaimana PWI memperhatikan karyawan pers yang diPHK pada masa krisis moneter ini? Bagaimana PWI memperhatikan kesejahteraan karyawan Pers, kalau PWI ingin meningkatkan citranya bukan sekedar kumpulan para warta- 
wan amplop?

\section{Penutup}

Pemerintahan bersih pada akhirnya bukanlah suatu yang given sifatnya. Permerintahan yang bersih adalah konsep yang selalu didesakkan kepentingan oleh masyarakat untuk lebih diperhatikan, karena pemerintahan macam begini adalah pemerintahan yang mau dikontrol masyarakatnya, mau dengan jujur memberikan kesempatan kelembagaan formal seperti DPR, Partai Politik, Organisasi Massa, Mahasiswa dan Lembaga Swadaya Masyarakat, untuk berfungsi secara lebih optimal dan lebih memperkuat posisi masyarakat di mata kekuasaan negara. Tak bisa kita sekedar menunggu goodwill dari pemerintah untuk bisa merubah dirinya. Kekuatan memaksa ini ada pada organisasi profesi yang mandiri, dalam konteks ini.

Dari kata kunci dari ini semua adalah organisasi, pengorganisasian. Harus ada kerja sama lintas profesi, lintas bidang, lintas horisontal, bahkan lintas batas kelas. Dengan kekuatan yang menggumpal sedemikian rupa, maka kekuasaan akan merasa bahwa kontrol adalah suatu keharusan untuk berlanjutnya pemerintahan. Tanpa suatu kontrol, tak ada jaminan berapa lama kekuasaan seperti ini akan bertahan, dan tiap kali kebijakan dilakukan tak lebih dari strategi tambal sulam yang tak banyak manfaatnya.

Agenda yang jelas untuk dunia jurnalistik atau pers adalah penghapusan kelembagaan ijin baik untuk media cetak maupun media elektronok. !jin adalah mekanisme pertama untuk melakukan sensor, dan berbagai jenis kooptasi lainnya. Setelah itu maka UU dan peraturan lain pun harus ditinjau yang melanggar UU di atasnya. Dan monopoli organisasi profesi haruslah di- tiadakan, karena pada dasarya mengingkari hakikat bahwa kebebasan untuk berorganisasi dijamin oleh Undang-Undang Dasar, dan hakikat kemanusiaan belaka, bahwa organisasi akan muncul dan bertumbuh sesuai dengan jamannya. Jika organisasi yang ada tidak bisa mengadopsi berbagai perkembangan yang ada maka ia hanya akan menjadi organisasi yang lapuk dan kuno, yang hanya tinggal sebentuk bangunan kuno berdebu namun tak memiliki roh apapun di dalamnya.

Kalau syarat minimal ini harus diusahakan terus-menerus, mungkin kita baru bisa berharap kalangan profesional juga punya kontribusi untuk mendesakkan munculnya pemerintahan yang bersih. Semoga.

\section{Bahan Bacaan Terpilih}

Hen Bagdikian, Media Monopoly, [2nd ed], Boston, Beacon Press, 1987.

Graham Murdock. "The New Mogul Empires Media Concentration and Control in The Age of Convergence", Media Development 4, 1994.

Daniel Dhakidae The State, The Rise of Capital and The Fall of Political Journalism; PoliticalEconomy of Indonesian News Industry, tesis Doktor dari Cornell University, 1991. Edward C Smith, Sejarah Pemberedelan

Pers di Indonesia, terj Jakarta Grafiti Pers, 1989.

Atmakusumah [ed] Mochtar Lubis; Wartawan Jihad, Jakrata Kompas 1992

Ignatius Haryanto, Pembredelan Pers di Indonesia: Kasus Koran Indonesia Raya, Jakarta, Lembaga Studi Pers dan Pembangunan, 1996.

Omi Intan Naomi, Anjing Penjaga; Pers

Pada Masa Orde Baru, Jakarta; Gorong-Gorong Budaya, 1996. 